\title{
Pengaruh Merokok Terhadap Faal Paru
}

\author{
Sri Wahyu Basuki, Dona Dewi Nilawati \\ Fakultas Kedokteran Universitas Muhammadiyah Surakarta \\ Laboratorium Fisiologi Fakultas Kedokteran Universitas Muhammadiyah Surakarta \\ Correspondence to: dr. Sri Wahyu Basuki, M.Kes \\ Email: sri_wahyu@ums.ac.id
}

\begin{abstract}
Indonesia is thethirdlargestcigaretteusersafter Chinaand India,which reached146.86 million inhabitants. Smoking behavior is engulfing all circles, including children. Dangers of smoking are undoubtedly makes a person not a long life. When compared with non smokers, smokers aged on average 10 years shorter and spend millions of dollars. Inhaled cigarette smoke may accelerate the decline in lung physiology caused by changes in the structure and function of the airway or parenchyma (tissue) in the lung. The objective of this study was to determine differences in pulmonary function (Vital Capacity/VC, Forced Vital Capacity/FVC, and Forced Vital Capacity of the first second/FEV1) in male smokers and non smokers at the Medical Faculty of Muhammadiyah University of Surakarta and determine the effect of smoking on pulmonary function. This study used analytical research design with cross sectional approach. The subject of this study was the active student and employee at the Medicine Faculty, Muhammadiyah University of Surakarta. Purposive sampling method was random sampling. The results were tested by statistical tests of independent t-test with SPSS 16.0.The sample size obtained was 40 people consisted of $20(50 \%)$ sample of smokers and $20(50 \%)$ sample of non-smokers. There was not difference $V C$ between male smokers and nonsmokers with $p=0.390$. There was difference FVC between male smokers and nonsmokers with $p=0.000$. There was difference FEV1 between male smokers and nonsmokers with $p=$ 0.025.This study showed the difference in FVC and FEV1 between male smokers and nonsmokers in the Medicine Faculty, Muhammadiyah University of Surakarta, but VC did not.
\end{abstract}

Keywords: VC, FVC, FEVI, Smokers and Non smokers

\section{PENDAHULUAN}

Jumlah orang yang merokok sangat banyak. Saat ini diperkirakan ada sekitar 1,3 milyar orang perokok di dunia (WHO, 2006). Menurut Suryopraogo (2009), laporan WHO pada tahun 2008 menyebutkan bahwa hampir $2 / 3$ perokok tinggal di 10 negara. Saat ini, Indonesia adalah negara terbesar ketiga pengguna rokok setelah Cina dan India yang mencapai 146.860 .000 jiwa. Perilaku merokok melanda semua kalangan. Merokok tidak hanya dilakukan oleh orang dewasa tetapi dilakukan pula oleh anakanak. Diperkirakan dari 70 juta jumlah anak di Indonesia, $37 \%$ atau 25,9 juta anak diantaranya merokok. Rokok secara luas telah menjadi salah satu penyebab kematian terbesar di dunia. Jumlah kematian akibat konsumsi rokok adalah lima juta orang per tahun. Jika dibandingkan dengan orang yang tidak merokok, usia para perokok rata-rata lebih pendek 10 tahun dan menghabiskan uang jutaan dolar (Depkes RI,2004)). Penggunaan Spirometri sebagai tes fungsi paru penting untuk menapis (screening) penyakit paru.
Dalam penelitian ini dapat dirumuskan suatu masalah:

1. Apakah ada perbedaan faal paru pada laki-laki perokok dan bukan perokok?

2. Apakah merokok dapat mempengaruhi faal paru?

Penelitian ini bertujuan untuk: .

1. Mengetahui perbedaan faal paru (Vital capasity/VC, force vital capasity/FVC, dan force expiratory volume, detik pertama/FEV1) pada laki-laki perokok dan bukan perokok.

2. Mengetahui pengaruh merokok terhadap faal paru

Penelitian ini bermanfaat untuk:

1. Manfaat Praktis

Dalam bidang kesehatan, jika diperoleh bukti bahwa nilai force vital capasity (FVC), Vital capasity (VC), dan force expiratory volume, detik pertama/ FEV1) pada perokok akan menurun maka diharapkan dapat memberikan manfaat: 
a. Mencegah bertambahnya jumlah perokok

b. Mengurangi jumlah perokok

c. Mencegah konsumsi rokok

d. Merubah perilaku buruk merokok

e. Mensosialisasikan budaya bebas asap rokok

f. Menanamkan pemikiran bahwa merokok itu dosa

\section{Manfaat Teoritis}

Dengan adanya penelitian ini dapat memberikan pengetahuan dan informasi tentang bahaya merokok. Dalam bidang pendidikan dapat digunakan sebagai pengetahuan tambahan yang dapat dikembangkan untuk penelitian lebih lanjut.

Hipotesis yang akan dibuktikan pada penelitian ini adalah:

1. Terdapat perbedaan nilai Vital capasity / VC, force vital capasity/FVC, dan force expiratory volume, detik pertama/ FEV1 pada laki-laki perokok dan bukan perokok

2. Merokok mempengaruhi faal paru

\section{METODE PENELITIAN}

Jenis penelitian ini adalah analitik observasional (non-experiment) dengan (cross sectional). Penelitian ini dilakukan di Universitas Muhammadiyah Surakarta dengan waktupenelitian selama bulan pada 2011. Populasi dalam penelitian ini adalah seluruh civitas akademika laki-laki di Universitas Muhammadiyah Surakarta. Sampel dalam penelitian ini adalah civitas akademika perokok dan bukan perokok usia 20-40 tahun di Universitas Muhammadiyah Surakarta, sejumlah 40 responden. Cara pengambilan sampel dengan terknik purposif sampling

Subyek penelitian memenuhi kriteria inklusi (penerima): civitas akademika, usia 2040 tahun, bagi perokok sudah merokok selama / lebih dari satu tahun, bersedia memberikan data yang nyata dan kooperatif dengan peneliti, dan kriteria eksklusi (penolak): sedang menderita penyakit paru, probandus tidak cakap melakukan pemeriksaan.

Variabel penelitian ini meliputi variabel bebas: Laki-laki perokok dan bukan perokok; variabel terikat: hasil Vital capasity/VC, force vital capasity/FVC, danforce expiratory volume, detik pertama/FEV1; dan variabel perancu: dikendalikan: tinggi badan dan umur dan tidak dikendalikan: lingkungan, nutrisi, dan aktifitas fisik.

\section{Definisi Operasional}

1. Vital capasity adalah volume udara maksimal yang bisa dikeluarkan setelah inspirasi maksimal. volume normal yang dihasilkan sekitar $4600 \mathrm{ml}$. Besar nilai VC pada lakilaki berdasarkan umur dan tinggi badan dapat ditentukan dengan rumus, $\mathrm{VC}(\mathrm{L})=5,44018+$ $0,04849 \times \mathrm{TB}+1,62398 \times \mathrm{C}-0,07768 \times(\mathrm{C} \times$ Umur) $\pm 0,4105$. Umur $\geq 21$ tahun, $\mathrm{C}=1 ; \leq 21$ tahun, $\mathrm{C}=0$.

Alat Ukur: spirometer

Skala pengukuran: kontinyu

2. FVC (Vital capasity Paksa)/FVC (Forced Vital Capacity) adalah volume udara maksimum dalam liter yang dapat dihembuskan secara paksa, sekeras-kerasnya dan secepat-cepatnya didahului dengan inspirasi sedalam-dalamnya. Umumnya dicapai dalam waktu 3 detik. Jumlahnya kira-kira empat liter.

Alat Ukur: spirometer

Skala pengukuran: kontinyu

3. Volume Ekspirasi Paksa detik pertama (VEP1) adalah sejumlah volume udara yang dihembuskan dalam detik pertama dari ekspirasi paksa yang didahului inspirasi sedalam-dalamnya. Jumlah volume ini kirakira 3,2 liter.

Alat Ukur: spirometer

Skala pengukuran: kontinyu

4. Perokok adalah seseorang yang mempunyai perilaku merokok sedikitnya satu batang setiap hari selama sekurang-kurangnya satu tahun.

Alat Ukur: spirometer

Skala pengukuran: nominal

5. Berat badan adalah ukuran tubuh dalam $\mathrm{Kg}$ Alat Ukur: timbangan

Skala pengukuran: kontinyu

6. Tinggi badan adalah ukuran panjang tubuh dalam centimeter

Alat Ukur: meteran

Skala pengukuran: kontinyu

7. Nutrisi adalah zat-zat gizi yang diperluka tubuh

8. Lingkungan adalah daerah tempat tinggal

9. Aktifitas fisik adalah latihan yang dilakukan seseorang secara teratur

\section{Instrumen Penelitian}

1. Kuesioner Status Perokok

Kuesioner ini berisi pertanyaan data responden tentang merokok yaitu apakah 
responden merokok, berapa jumlah batang rokok yang dihabiskan dalam sehari, sudah berapa lama merokok dan juga penyebab merokok. Kuesioner ini bertujuan untuk mengetahui status responden apakah perokok atau bukan perokok.

2. Alat spirometer

Spirometer ini terdiri dari sebuah drum yang dibalikkan di atas bak air, dan drum tersebut diimbangi oleh suatu beban. Dalam drum terdapat gas untuk bernapas, biasanya udara atau oksigen dan sebuah pipa yang menghubungkan mulut dengan ruang gas.

\section{Teknik Pengambilan Data}

Pengambilan data dilakukan dengan cara membagikan kuesioner kepada responden guna memperoleh sampel yang dibutuhkan untuk pengambilan data. Setelah memperoleh sampel yang diperlukan, dilakukan pengukuran Vital capasity/VC, force vital capasity/FVC, dan force expiratory volume, detik pertama/FEV1 pada masing-masing sampel dengan spirometer.

\section{Skema Penelitian}

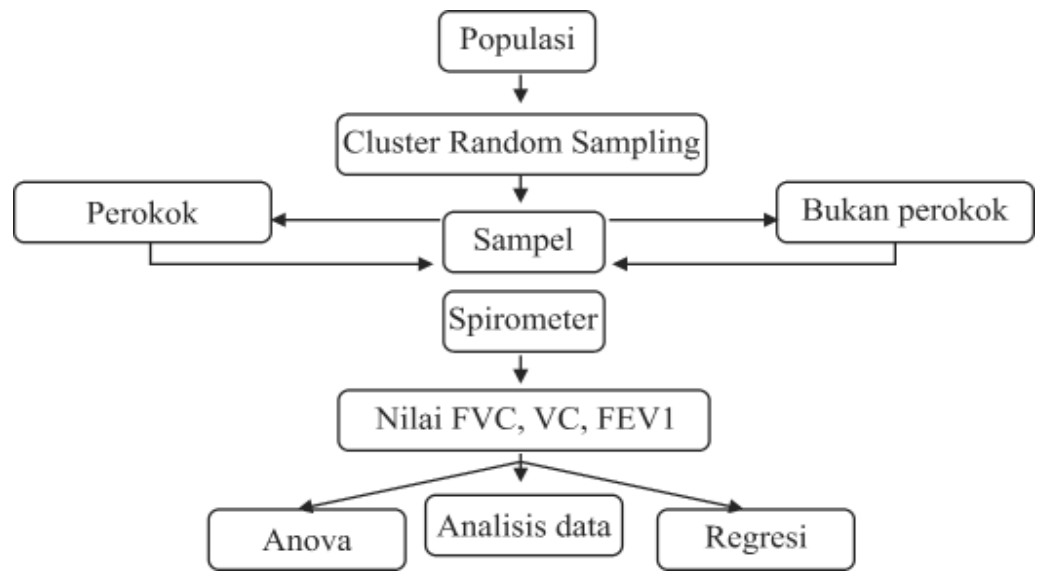

\section{Analisis Data}

Untuk menghitung uji statistik digunakanuji t, sedang untuk menguji variabel perancu dengan korelasi bivariat dengan program SPSS 16.0 for windows, dengan interpretasi:

a. Jika $t$ hitung $\leq \mathrm{t} \alpha=0,01$ maka hasil uji dinyatakan sangat signifikan.

b. Jika $t \alpha=0,05 \leq \mathrm{t}$ hitung $\leq \mathrm{t} \alpha=0,05$ maka hasil uji dinyatakan signifikan.

c. Jika thitung $>\operatorname{t} \alpha=0,05$ maka hasil uji dinyatakan tidak signifikan

\section{HASIL DAN PEMBAHASAN Hasil Penelitian}

Penelitian tentang pengaruh merokok terhadap faal paru di Fakultas Kedokteran Universitas Muhammadiyah Surakarta dilaksanakan pada bulan November-Desembsr 2011 dengan menggunakan metode pengambilan data purposive sampling, Keseluruhan sampel berjenis kelamin laki-laki berusia antara 15-44 tahun dan telah memenuhi kriteria inklusi. Dari 40 sampel tersebut diperoleh data sebagai berikut:
Tabel 1. Frekuensi Distribusi Perokok dan Bukan perokok

\begin{tabular}{ccc}
\hline Status & Jumlah Responden & $\%$ \\
Perokok & 20 & 50 \\
Bukan Perokok & 20 & 50 \\
Total & 40 & 100 \\
\hline
\end{tabular}

Berdasarkan tabel 1, menunjukkan tentang jumlah responden di dalam setiap kelompok adalah sama, yaitu 20 responden. 
Tabel 2. Distribusi Responden Berdasarkan Rerata (Mean) umur dan tinggi badan

\begin{tabular}{cc}
\hline Kelompok Responden & Mean \\
umur & 22.87 \\
Tinggi badan & 170.82 \\
\hline
\end{tabular}

Tabel 2 menunjukkan rata-rata umur responden adalah 22.87 tahun sedangkan rata-rata tinggi badan responden adalah $170.82 \mathrm{~cm}$.

Tabel 3. Distribusi Rerata (Mean) Nilai VC, FVC, FEV1

\begin{tabular}{|c|c|c|c|c|}
\hline $\begin{array}{l}\text { Kelompok } \\
\text { Responden }\end{array}$ & $\mathbf{N}$ & mean VC & Mean FVC & $\begin{array}{c}\text { Mean } \\
\text { EV1 }\end{array}$ \\
\hline Perokok & 20 & 3030,00 & 2722,86 & 2099,50 \\
\hline bukan perokok & 20 & 3195,00 & 3528,57 & 2559,00 \\
\hline
\end{tabular}

Tabel 3 menunjukkan rata-rata nilai FVC pada perokok dan bukan perokok. Dari tabel tersebut diperoleh data bahwa rata-rata nilai VC perokok lebih rendah yaitu 3030,00 ml dibandingkan bukan perokok yaitu 3195,00 ml. Rata-rata nilai FVC perokok lebih rendah yaitu $2722,86 \mathrm{ml}$ dibandingkan bukan perokok yaitu 3528,57 ml. Rata-rata nilai FEV1 perokok lebih rendah yaitu 2099,50 $\mathrm{ml}$ dibandingkan bukan perokok yaitu $2559,00 \mathrm{ml}$.

Untuk keperluan analisis uji t maka data harus terdistribusi normal. Uji normalitas data menggunakan uji Shapiro-Wilk karena sampel yang diambil kurang dari 50 sampel. Berikut ini hasil test normalitas data menggunakan uji shapiro-wilk.

Tabel 4. Uji Normalitas Data (Shapiro-Wilk)

\begin{tabular}{lccc}
\hline & Kelompok & \multicolumn{2}{c}{ Shapiro-Wilk } \\
\cline { 3 - 4 } & Responden & Frekuensi & p value \\
\hline VC & perokok & 20 & 0.301 \\
& bukan perokok & 20 & 0.373 \\
FVC & perokok & 20 & 0.427 \\
responden & bukan perokok & 20 & 0.164 \\
FEV1 & perokok & 20 & 0.149 \\
responden & bukan perokok & 20 & 0.194 \\
\hline
\end{tabular}

Berdasarkan tabel 4 diperoleh bahwasemua responden mempunyai nilai $\mathrm{p}>0,05$, sehingga dapat disimpulkan bahwa semua data responden terdistribusi normal.

Data yang telah terdistribusi normal, dilakukan lavene's test untuk mengetahui homo- genitas dari varian kelompok perokok dan bukan perokok. Berikut ini hasil lavene's test.

Tabel 5. Lavene's Test untuk Mengetahui Homogenitas dari Varian Kelompok Perokok dan Bukan Perokok.

\begin{tabular}{clcc}
\hline & & \multicolumn{2}{c}{$\begin{array}{c}\text { Levene's Test for } \\
\text { Equality } \\
\text { of Variances }\end{array}$} \\
\cline { 3 - 4 } VC & \begin{tabular}{l} 
Equal variances assumed \\
\cline { 3 - 3 } Equal variances not assumed
\end{tabular} & \multicolumn{1}{c}{ Sig } \\
FVCP & $\begin{array}{l}\text { Equal variances assumed } \\
\text { Equal variances not assumed } \\
\text { FEV1 }\end{array}$ & $\begin{array}{l}\text { Equal variances assumed } \\
\text { Equal variances not assumed }\end{array}$ & .474 \\
\hline
\end{tabular}

Berdasarkan Levene's test for equality of variance's, menunjukkan nilai $\mathrm{p}=0,474$ untuk $\mathrm{VC}$, dan nilai $\mathrm{p}=0,123$ untuk FVC, karena nilai $\mathrm{p}<0,05$ maka dapat disimpulkan bahwa varian kelompok perokok dan bukan perokok adalah sama. Karena varian sama, maka untuk melihat hasil uji t pada VC dan FVC menggunakan equal variances assumed. Sedangkan hasil FEV1 menunjukkan nilai $\mathrm{p}=0,011$, karena nilai $\mathrm{p}<0,05$ maka dapat disimpulkan bahwa varian kelompok perokok dan bukan perokok adalah tidak sama. Karena varian tidak sama, maka untuk melihat hasil uji t menggunakan equal variances not assumed.

Tabel 6. Independent sampel test

\begin{tabular}{|c|c|c|c|c|}
\hline & \multirow{2}{*}{$\begin{array}{c}\text { Sig. } \\
\text { (2-tailed) }\end{array}$} & \multirow{2}{*}{$\begin{array}{c}\text { Perbedaan } \\
\text { Rerata }\end{array}$} & \multicolumn{2}{|c|}{ Nilai IK 95\% } \\
\hline & & & $\begin{array}{c}\text { Batas } \\
\text { Bawah }\end{array}$ & $\begin{array}{c}\text { Batas } \\
\text { Atas }\end{array}$ \\
\hline VC Responden & 0,390 & 165,000 & $-219,443$ & 549,443 \\
\hline FVC Responden & 0,000 & 808,000 & 559,730 & 1056,270 \\
\hline $\begin{array}{c}\text { FEV1 } \\
\text { Responden }\end{array}$ & 0,025 & 459,500 & 60,369 & 858,630 \\
\hline
\end{tabular}

Dari tabel 6 di atas, hasil uji t dua kelompok tidak berpasangan yaitu antara perokok dan bukan perokok terhadap VC menunjukkan $\mathrm{p}=0,390$, dengan perbedaan rerata 165,000 , nilai IK $95 \%$ adalah antara $-219,443$ sampai 549,443 ; FVC menunjukkan $\mathrm{p}=0,000$, dengan perbedaan rerata 808,000 , nilai IK $95 \%$ adalah antara 559,730 sampai -1056,270; FEV1 menunjukkan $\mathrm{p}=0,025$ dengan perbedaan rerata 459,500 nilai IK $95 \%$ adalah antara 60,369 sampai 858,630. 
Hasil di atas menunjukkan nilai p pada FVC dan FEV1 kurang dari 0.05, sedangkan VC lebih dari 0,05 . Dengan demikian dapat disimpulkan bahwa ada perbedaan yang bermakna nilai FVC dan FEV1 antara perokok dan bukan perokok, tetapi tidak ada perbedaan yang bermakna nilai $\mathrm{VC}$ antara perokok dan bukan perokok.

Tabel 7. Uji Normalitas Data (Shapiro-Wilk) terhadap Umur dan Tinggi Badan

\begin{tabular}{ccc}
\hline Kelompok & \multicolumn{2}{c}{ Shapiro-Wilk } \\
\cline { 2 - 3 } Responden & frekuensi & p value \\
\cline { 2 - 3 } Umur & 40 & 0.000 \\
Tinggi badan & 40 & 0.312 \\
\hline
\end{tabular}

Berdasarkan tabel 7 diperoleh bahwa data umur mempunyai nilai $\mathrm{p}=0,000$, karena nilai $\mathrm{p}$ $<0,05$ sehingga dapat disimpulkan bahwa data umur tidak terdistribusi normal. Sedangkan data tinngi badan mempunyai nilai $\mathrm{p}=0,312$, karena nilai $p>0,05$ sehingga dapat disimpulkan bahwa data tinggi badan terdistribusi normal.
Data umur dianalisis dengan menggunakan korelasi spermean, sedangka data tinngi badan dianalisis menggunakan korelasi pearson. Berikut ini hasil analisis tersebut: Hasil tabel 8 menunjukkan nilai $\mathrm{p}$ uji spearmen antara umur dan VC adalah 0,038, karena nilai $\mathrm{p}<0,05$ maka terdapat korelasi antara umur dan $\mathrm{VC}$ dengan nilai korelasi $-0,329$, korelasi bersifat negatif dengan kekuatan hubungan yang kuat. Nilai $\mathrm{p}$ uji pearson antara tinggi badan dan $\mathrm{VC}$ adalah 0,008 , karena nilai $\mathrm{p}<0,05$ maka terdapat korelasi antara umur dan VC dengan nilai korelasi 0,415 , korelasi bersifat positif dengan kekuatan hubungan yang kuat. Nilai $\mathrm{p}$ uji pearson antara tinggi badan dan FEV1 adalah 0,012, karena nilai $\mathrm{p}<0,05$ maka terdapat korelasi antara umur dan VC dengan nilai korelasi 0,394 , korelasi bersifat negatif dengan kekuatan hubungan yang kuat. Sedangkan hubungan umur dengan FVC dan FEV1 tidak bermakna karena nilai $\mathrm{p}>0,05$, demikian juga hubungan tinggi badan dan FVC tidak bermakna kerana nilai $\mathrm{p}>0,05$.

Tabel 8. Uji korelasi bivariat terhadap Umur dan Tinggi Badan

\begin{tabular}{ccccc}
\hline \multirow{2}{*}{ Data } & Umur dengan & Spearmen & Tinggi Badan Sig & Dg Pearson \\
\cline { 3 - 5 } & Sig & Koefisien Korelasi & & Koefisien Korelasi \\
\hline VC & 0,038 & $-0,329$ & 0,008 & 0,415 \\
FVC & 0,551 & 0,097 & 0,462 & 0,120 \\
FEV1 & 0,116 & 1,000 & 0,012 & 0.394 \\
\hline
\end{tabular}

\section{PEMBAHASAN}

Pada penelitian ini jumlah sampel yang didapatkan adalah 40 orang yang terdiri dari 20 orang perokok dan 20 orang bukan perokok, sebagaimana terlihat pada tabel 1. Jumlah kedua kelompok sampel sama dan jumlah ini sudah memenuhi kriteria minimal sampel yang disebutkan pada bab III. Dengan demikian sampel ini representatif.

Pada tabel 2, diketahui bahwa rata-rata umur responden adalah 22,87 tahun. Pertumbuhan optimal paru-paru dicapai pada usia 19 tahun untuk laki-laki. Penurunan fungsi paru menurun dengan bertambahnya usia dan tampak cepat setelah usia 40 tahun (Yunus, 1990).

Daya tahan kardiorespirasi meningkat dari masa kanak-kanak dan mencapai puncaknya pada usia 20-30 tahun. Sesudah itu daya tahan kardiorespirasi akan menurun. Penurunan ini terjadi karena organ yang mengambil oksigen yaitu paru mulai menurun fungsinya, selain itu organ yang mendistribusikan oksigen ke seluruh tubuh yaitu jantung dan pembuluh darah fungsinya juga menurun. Penurunan fungsi ini terjadi karena bertambahnya usia. Umur responden tidak lebih dari 44 tahun supaya faktor umur tidak mempengaruhi penurunan VEP1 sendiri dan faktor yang menyebabkan penurunan fungsi paru tidak hanya dari rokok tapi dapat disebabkan oleh polusi udara yang terdiri dari polusi di dalam ruangan (indoor) yang berupa asap kompor, asap kayu bakar dan polusi di luar ruangan (outdoor), seperti gas buang industri, gas buang kendaraan bermotor, debu jalanan, dan lain-lain. Polusi di tempat kerja, seperti bahan kimia, debu / zat iritasi, gas beracun, dan lain-lain serta penyakit paru (Yunus, 1990). 
Pada tabel 2, diketahui juga bahwa ratarata tinggi badan responden adalah 170,82 tahun. Melihat rata-rata tinggi badan yang cukup tinggi akan menghasilkan nilai faal paru yang tinggi juga , mengingat tinggi badan meningkatkan nilai faal paru berdasarkan rumus $\mathrm{FVC}(\mathrm{L})=5,44018$ $+0,04849 \times \mathrm{TB}+1,62398 \times \mathrm{C}-0,07768 \times(\mathrm{C}$ $\mathrm{x}$ Umur) $\pm 0,4105$. Umur $\geq 21$ tahun, $\mathrm{C}=1$; $\leq 21$ tahun, $\mathrm{C}=0$ (Djojodibroto, 2009).

Pada tabel 3, didapatkan mean (rata-rata) nilai ,VC, FVC, dan VEP1 perokok yang diteliti masing-masing lebih rendah dibandingkan nilai VC, FVC, dan FEV1 responden bukan perokok. Hal ini menunjukkan ada perbedaan secara deskriptif. Apakah perbedaan ini bermakna atau tidak maka dilakukan analisis uji $\mathrm{T}$.

Analisis dengan uji $\mathrm{T}$ harus mensyaratkan adanya normalitas data yang diuji. Pada penelitian ini karena jumlah sampel kurang dari 50 maka untuk menguji normalitas data menggunakan uji Shapiro Wilk. Pada tabel 4 dapat diketahui bahwa semua data responden, yaitu VC, FVC, dan FEV1 terdistribusi normal. Dengan demikian dapat dilakukan analisis uji $\mathrm{T}$.

Pemilihan analisis uji $\mathrm{T}$ dilakukan berdasarkan hasil Levene's test for equality of variance's. Hasil Levene's test for equality of variance's pada tabel 5 menunjukkan bahwa varian kelompok VC dan FVC sama sehingga hasil uji $t$ pada VC dan FVC menggunakan equal variances assumed. Sedangkan varian kelompok FEV1 tidak sama sehingga hasil uji t pada FEV1 menggunakan equal variances not assumed.

Hasil uiji T tidak berpasangan, pada tabel 6 menunjukkan nilai $\mathrm{p}$ pada FVC dan FEV1 kurang dari 0,05 , sedangkan VC lebih dari 0,05 . Dengan demikian dapat disimpulkan bahwa ada perbedaan yang bermakna nilai FVC dan FEV1 antara laki-laki perokok dan bukan perokok di Fakultas Kedokteran Universitas Muhammadiyah Surakarta., tetapi tidak ada perbedaan yang bermakna nilai VC antara laki-laki perokok dan bukan perokok di Fakultas Kedokteran Universitas Muhammadiyah Surakarta.

Merokok merupakan faktor risiko utama terjadinya penyakit paru obstruksi kronis (PPOK). Rokok mengandung 4.000 jenis bahan kimia. Rokok memiliki dua komponen yaitu 1) komponen gas, bagian yang dapat melewati filter ataupun hasil dari pembakaran tidak sempurna rokok, antara lain $\mathrm{CO}, \mathrm{CO}$, oksida-oksida nitrogen, amonia, gas N-nitrosamine, hidrogen sianida, sianogen, peroksida, oksidan senyawa belerang, aldehid dan keton. 2) komponen padat, bagian hasil saringan yang tertinggal pada filter rokok, sebagian besar terdiri dari unsur nikotin dan tar (Triswanto, 2007).

Banyaknya zat kimia yang terdapat dalam rokok yang paling berkaitan dengan berbagai penyakit akibat merokok adalah nikotin, tar, dan $\mathrm{CO}$ yang merupakan sumber oksidan. Nikotin merupakan jenis obat perangsang yang dapat merusak jantung dan sirkulasi darah (disfungsi endotelial), serta dapat menimbulkan ketagihan sedangkan pada paru-paru nikotin akan menghambat aktivitas silia. Tar mengandung bahan kimia beracun perusak sel paru dan penyebab kanker. Tar berupa cairan berwarna coklat tua dan hitam yang lengket dan menempel pada paru-paru yang menyebabkan paru-paru perokok berbintik coklat atau hitam. Tar yang ada di dalam asap rokok juga menyebabkan paralise di saluran pernapasan. CO (karbonmonoksida) merupakan gas beracun yang menyebabkan penurunan kemampuan butir darah merah yang mengangkut oksigen sehingga sel tubuh yang kekurangan oksigen akan melakukan spasme yaitu menciutkan pembuluh darah dan bila proses ini berlangsung terus menerus, maka pembuluh darah akan mudah rusak dengan terjadinya proses aterosklerosis. Pada akhirnya semua bahan-bahan berbahaya rokok akan menstimulus produksi berlebihan dari radikal bebas atau oksidan dalam tubuh manusia (Triswanto, 2007; Aulia, 2010; Patrianto, 2005).

Merokok mengakibatkan proses inflamasi kronik pada alveoli dan saluran napas bawah. Selain itu, merokok mengganggu proses perbaikan jaringan paru dengan menghambat sintesis elastin, pengerahan dan proliferasi fibroblas, produksi matriks serta remodeling matriks ekstraseluler. Untuk terjadinya obstruksi (hambatan) pada jalan nafas yang disebabkan oleh asap rokok terdapat beberapa faktor seperti lama merokok, jumlah batang rokok yang dikonsumsi perhari, dan olahraga (life style) (Patrianto, 2005).

Beberapa penelitian sebelumnya mengatakan bahwa faal paru pada perokok akan mengalami penurunan oleh adanya zat oksidan yang akan masuk ke dalam saluran pernapasan dengan cara partikulat yang terkandung dalam asap rokok akan mengendap di lapisan mukus 
yang melapisi mukosa bronkus, sehingga menghambat aktivitas silia yang berakibat iritasi jalan napas yang akan menyebabkan paralisis silia, bronkospasme, hiperplasia, dan hipertropi kelenjar mukosa dan goblet. Semua ini akan menimbulkan penebalan dinding jalan napas, sekresi lendir meningkat disertai bronkospasme menyebabkan terjadinya sumbatan mukus yang menyumbat jalan napas. Apabila lendir dalam saluran napas ini tidak dikeluarkan secara efektif oleh mukosiliar, maka lendir tersebut merupakan media tempat berkumpulnya kuman yang memudahkan infeksi bakterial, pada proses selanjutnya terjadi erosi epitel serta pembentukan jaringan parut. Selain itu terjadi juga metaplasi skuamosa dan penebalan lapisan skuamosa. Hal ini akan menimbulkan stenosis dan obstruksi saluran napas yang bersifat irreversibel (Setiawan, 1999). Herminto (1998) juga menyatakan bahwa, penurunan fungsi paru akan mulai terlihat pada lama pernapasan yang terjadi pada 2 tahun dan seterusnya akibat debu dan kebiasaan merokok. Tetapi menurut Hans tahun 2003 hanya sebagian kecil dari perokok akan bermanifestasi klinis menjadi penyakit paru obstruksi atau terjadinya obstruksi dan hanya sebagian kecil yang berkembang menjadi kerusakan fungsi paru yang berat.

Hasil penelitian yang mendukung penelitian ini pernah dilakukan sebelumnya oleh Setiawan (1999) yang menyimpulkan bahwa didapatkan perbedaan yang bermakna pada nilai FEV1 antara perokok dan bukan perokok dengan $p<0,05$.(10)

Hasil penelitian tentang FVC ini sesuai dengan pendapat Mangunnegoro (1993) sebagai berikut: partikulat yang terkandung dalam asap rokok akan mengendap di lapisan mukus yang melapisi mukosa bronkus, sehingga menghambat aktifitas silia yang berakibat iritasi jalan napas dan menyebabkan paralisis silia, bronkospasme, hiperplasia serta hipertropi kelenjar mukosa dan goblet. Semua ini menimbulkan penebalan dinding jalan napas, sekresi lendir meningkat disertai bronkospasme menyebabkan terjadinya sumbatan mukus yang menyumbat jalan napas. Proses selanjutnya akan terjadi erosi epitel dan pembentukan jaringan parut. Keadaan ini dapat menimbulkan obstruksi saluran napas yang irreversibel.

Berdasarkan hasil penelitian sebelumnya yang dilakukan oleh Setiawan (1999) menunjukkan ada perbedaan nilai faal paru antara perokok dan bukan perokok dengan perbedaan FVC $(\%)$ secara statistik bermakna $(\mathrm{p}<0,05)$ (12). Hanida Trisnawati (2007) menunjukkan bahwa ada hubungan antara kebiasaan merokok dengan vital capasity paru tukang ojek di Alunalun Ungaran Kabupaten Semarang bulan Maret tahun 2007 dengan nilai $\mathrm{p}$ value sebesar 0,002 (Trisnawati, 2007).

Penelitian di Turki pada 360 anak usia 9-13 tahun, menunjukkan bapak perokok (paternal smoking) sangat erat kaitannya dengan penguranganforce vital capasity atau Force Vital Capacity (FVC), laju ekspirasi paksa pada 25\% sampai $75 \%$ vital capasity atau Force Expiratory Flow between $25 \%$ and $75 \%$ of FVC (FEF2575) dan laju ekspirasi puncak. Keadaan ini terjadi karena di Turki lebih banyak pria perokok dibandingkan wanita. Penelitian di Cina juga melaporkan bapak yang merokok lebih dari 30 batang sehari berkaitan dengan pengurangan signifikan pada FEV1 dan FVC pada keturunannya. Di Cina, prevalensi pria perokok $61 \%$, sedangkan wanita hanya sekitar 7\% (Universitas Sumatera Utara, 2011).

Adapun hasil VC yang menunjukkan tidak ada perbedaan yang bermakna bukan berarti mematahkan teori-teori yang sebelumnya. Pada pemeriksaan yang benar, umumnya besarnya nilai VC sama dengan FVC. Adanya perbedaan hasil ini mungkin disebabkan kesalahan prosedur pemeriksaan pada responden, responden tidak bisa menghirup dan menghempaskan nafas dengan optimal.

Pada penelitian ini juga dilakukan analisis terhadap variabel perancu, yaitu umur dan tinggi badan. Uji normalitas data, pada tabel 7 , menunjukkan bahwa data umur tidak terdistribusi normal, data tinggi badan terdistribusi normal. Dengan demikian maka Data umur dianalisis dengan menggunakan korelasi spermean, sedangkan data tinggi badan dianalisis menggunakan korelasi pearson.

Analisis bivariat spearmen menunjukkan hubungan yang bermakna antara umur dan VC dengan nilai korelasi $-0,329$, korelasi bersifat negatif dengan kekuatan hubungan yang kuat. Hubungan umur dengan FVC dan FEV1 tidak bermakna karena nilai $p>0,05$.

Analisis bivariat pearson menunjukkan hubungan yang bermakna antara tinggi badan dan VC dengan nilai korelasi 0,415 , korelasi bersifat 
positif dengan kekuatan hubungan yang kuat. Hubungan yang bermakna antara tinggi badan dan FEV1 dengan nilai korelasi 0,394, korelasi bersifat positif dengan kekuatan hubungan yang kuat. Hubungan tinggi badan dengan FVC tidak bermakna karena nilai $\mathrm{p}>0,05$.

\section{KESIMPULAN}

Berdasarkan penelitian ini, dapat diambil kesimpulan yaitu :

1. Tidak terdapat perbedaan yang bermakna Vital capasity (VC) antara laki-laki perokok dan bukan perokok di Universitas Muhammadiyah Surakarta dengan nilai signifikasi $\mathrm{p}=0,390$.

2. Terdapat perbedaanforce vital capasity (FVC) antara laki-laki perokok dan bukan perokok di Universitas Muhammadiyah Surakarta dengan nilai signifikasi $\mathrm{p}=0,000$.

3. Terdapat perbedaan volume ekspirasi paksa detik pertama (VEP1) antara laki-laki perokok dan bukan perokok di Universitas Muhammadiyah Surakarta dengan nilai signifikasi $\mathrm{p}=0,025$.

4. Merokok dapat menurunkan FVC dan FEV1.

\section{SARAN}

berikut:

Saran pada penelitian ini adalah sebagai

1. Sebaiknya setiap orang menghindari konsumsi rokok sejak usia dini mengingat bahaya yang ditimbulkan.

2. Sebaiknya pemerintah ataupun instansi yang terkait mengadakan penyuluhan tentang rokok dari beberapa aspek yaitu agama, kesehatan, ekonomi, dan lain-lain.

3. Dilakukan penelitian lebih lanjut dengan mengendalikan faktor perancu, populasi lebih banyak.

\section{UCAPAN TERIMA KASIH}

Kami ucapkan terima kasih kepada pihakpihak yang telah membantu terselesaikannya penelitian ini, yaitu: Laboratorium fisiologi di biomedik.Fakultas Kedokteran Universitas Muhammadiyah Surakarta

\section{DAFTAR PUSTAKA}

Aula, L. 2010. Stop Merokok (Sekarang Atau Tidak Sama Sekali). Yogyakarta: Garai Ilmu

Depkes RI. 2004. http://www.depkes.go.id/index. php?option=articles. Download tanggal 7 Maret 2011
Djojodibroto, D. 2009. Respirologi. Jakarta: EGC pp. $1-52$

Herminto, 1998. Hubungan Lama Pencemaran Debu Kayu terhadap Gangguan Fungsi Paru Tenaga Kerja di Perusahaan CV Nila's Wood Arts Surakarta. Surakarta.

Johan, B. 2011 "Bahaya Merokok- Bagaimana Mengatasinya Secara Alami?". http:// www.antirokok.co.id/product index. htm. (14 Agustus 2011).

Patrianto, A \& Yunus, F. 2005. Kuliti Hidup penderita PPOK Jurnal Respirologi Indonesia, Vol. 25, No 2, april 2005

Setiawan, AM. 1999. Perbedaan Nilai Faal Paru Antara Perokok dengan Bukan Perokok Pada Mahasiswa Fakultas Kedokteran UNS. Skripsi

Suryopraogo, N. 2009. Kupas Tuntas Kesehatan Remaja dari A-Z. Yogyakarta: Signal

Tandra, Hans. 2003. Merokok dan Kesehatan. http://www.domeclinic.com/lifestyle/ merokok-a-kesehatan.pdf Download tanggal 18 April 2011

Trisnawati, H. 2007. Faktor-Faktor Yang Berhubungan Dengan Vital capasity Paru Tukang Ojek Di Alun-Alun Ungaran Kabupaten Semarang Bulan Maret Tahun 2007. http://www.scribd. com/doc/40494820/Doc Download tanggal 14 Juni 2011

Triswanto, SD. 2007. http://www.linkpdf.com/ download/d1/kriteria-perokok-menurutdepkes-.pdf Download tanggal 29 April 2011

Universitas Sumatera Utara. 2011. http://repository.usu.ac.id/ bitstream/123456789/23520/4/ Chapter\%20II.pdf Download tanggal 14 Juni 2011Download tanggal 9 Maret 2011

World Health Organitation. 2006. http://www. who.int Download tanggal 9 Maret 2011

World Health Organitation. 2008. http:// whoindonesia.healthrepository. org/bitstream/123456789/643/1/ B ooklet $\% 20$ of $\% 20$ Tobacco $\% 20$ Economics...\%28INO $\% 20 \mathrm{FFC} \% 20$ $011 \% 20 \mathrm{XK} \% 2008 \% 20 \mathrm{SE}-09$ 228726\%29.pdf

Yunus, F. 1990. Proyek Pneumobile Indonesia Paru. Jakarta: FKUIpp35-7 